\title{
Assessment of vertical scar migration after classical abdominoplasty followed by lower abdominal flap fixation
}

\author{
Avaliação da migração vertical da cicatriz pós-abdominoplastia clássica com \\ fixação do retalho abdominal inferior
}

\author{
Paul Kaufmann $^{1}$ \\ Luís Gustavo Moraes \\ $\mathrm{PRADO}^{1}$ \\ Vinícius Volpe D'Angieri \\ BASILE $^{1}$ \\ Francesco MazZarone ${ }^{2}$ \\ Ivo Pitanguy ${ }^{3}$
}

Study conducted at the Service of Plastic Surgery of Professor Ivo Pitanguy, Santa Casa de Misericórdia do Rio de Janeiro,

Rio de Janeiro, RJ, Brazil.

Submitted to SGP (Sistema de Gestão de Publicações/Manager Publications System) of RBCP (Revista Brasileira de Cirurgia Plástica/Brazilian Journal of Plastic Surgery).

Received: July 16, 2011

Accepted: August 9, 2011

\begin{abstract}
Background: In plastic surgery, the postoperative scar is a frequent concern. It is very important for the surgeon to understand the natural evolution of the scar. The abdominoplasty scar has a natural tendency to move upwards over time. In this study, the extent of natural vertical scar migration after abdominoplasty was calculated and the effect of fixing the lower abdominal flap to prevent this rise was assessed. Methods: This prospective and randomized study was conducted at the $38^{\text {th }}$ Nursing service of Santa Casa de Misericórdia do Rio de Janeiro, during 2010, and included 20 female patients with an indication for abdominoplasty. The patients were randomly divided into two groups, A and B. Classical abdominoplasty was performed in group A patients, according to the technique recommended by Prof. Ivo Pitanguy. Patients in group B also underwent lower abdominal flap fixation by suturing of Scarpa's fascia and the rectus abdominis muscle aponeurosis. At both two weeks and six months after surgery, the distance of vertical scar movement was measured in 16 patients after application of exclusion criteria. The average vertical migration and the mean difference between the groups were calculated. Results: The average difference between the groups in vertical migration throughout the scar was $0.4 \mathrm{~cm}$, with a mean overall migration of $1.06 \mathrm{~cm}$ and $0.68 \mathrm{~cm}$ in groups A (control group) and B (cases with fixation), respectively. Conclusions: The scar formed after abdominoplasty undergoes vertical migration over time; this migration is decreased when the lower abdominal flap is fixed. The surgeon should be aware of scar migration for better planning of the incision location.
\end{abstract}

Keywords: Abdomen/surgery. Cicatrix. Surgical flaps.

\section{RESUMO}

Introdução: Na cirurgia plástica, uma constante preocupação é a cicatriz pós-operatória. É muito importante para o cirurgião conhecer a evolução natural da cicatriz. A cicatriz de abdominoplastia tem a tendência natural de subir com o passar do tempo. Neste estudo, calculou-se a migração vertical natural da cicatriz pós-abdominoplastia, avaliando o efeito da fixação do retalho abdominal inferior na prevenção dessa ascensão. Método: Estudo prospectivo e randomizado, realizado na $38^{\mathrm{a}}$ Enfermaria da Santa Casa de Misericórdia do Rio de Janeiro durante o ano de 2010, incluindo 20 pacientes do sexo feminino com indicação de abdominoplastia, divididas em dois grupos, A e B, aleatoriamente. Nas pacientes do grupo A, foi realizada abdominoplastia clássica, segundo técnica preconizada pelo Prof. Ivo Pitanguy, e no grupo B foi incluída a fixação do retalho abdominal inferior por meio de sutura interessando a fáscia de Scarpa e a aponeurose do músculo reto abdominal. Duas semanas e seis meses após a cirurgia, foi medida a distância vertical em 16 pacientes, após aplicação dos critérios de exclusão, calculando-se a média de migração vertical e a diferença média entre os dois grupos. Resultados: A diferença média de migração vertical ao longo de toda a cicatriz foi de 0,4 $\mathrm{cm}$, sendo a média geral de migração nos grupo A (controle) e B (casos com fixação) de $1,06 \mathrm{~cm}$ e $0,68 \mathrm{~cm}$, respectivamente. Conclusões: A cicatriz pós-abdominoplastia sofre migração vertical ao longo do tempo, sendo menor quando o retalho inferior é fixado. O cirurgião deve estar ciente da migração sofrida pela cicatriz para melhor planejamento da posição de sua incisão.

Descritores: Abdome/cirurgia. Cicatriz. Retalhos cirúrgicos.

1. General surgeon, post-graduation student at Instituto Ivo Pitanguy, Rio de Janeiro, RJ, Brazil.

2. Full member of the Brazilian Society of Plastic Surgery (SBCP), president of Instituto Ivo Pitanguy de Pós-Graduação Médica em Cirurgia Plástica, Pontifícia Universidade Católica do Rio de Janeiro (PUC-RJ) and Instituto de Pós-Graduação Médica Carlos Chagas, Rio de Janeiro, RJ, Brazil.

3. Patron of SBCP, member of the National Academy of Medicine and Brazilian Academy of Letters, full professor for the medical post-graduate course of plastic surgery at PUC-RJ and Instituto de Pós-Graduação Médica Carlos Chagas, Rio de Janeiro, RJ, Brazil. 


\section{INTRODUCTION}

Abdominoplasty surgery was first described in Voloir's thesis in 1890. At the beginning of the last century, other surgeons, such as Passot, Biesenberger, Thorek, and Fournier, published their versions of the abdominoplasty technique ${ }^{1}$. The procedure has since been refined over the past 50 years, as can be evidenced in the publications of Gonzalez-Ulloa, Pitanguy, Sinder, Baroudi, and Lockwood, amongst others ${ }^{1,2}$.

Regardless of the technique used, it is necessary to prioritize a good functional and aesthetic result. In this context, an almost imperceptible scar is the aim of every surgeon and patient alike. A scar considered excellent is small, thin, flat, and hidden in a skinfold.

In abdominoplasties performed in the $38^{\text {th }}$ Nursing service of Santa Casa de Misericórdia do Rio de Janeiro (Rio de Janeiro, RJ), vertical migration of the scar has been noticed. The ability to predict the extent of scar migration would enable the surgeon to carry out better planning of the incision. Moreover, it is important to establish whether any suturing technique can fix the scar in its original position and prevent its vertical migration. An extensive review of the medical literature yielded no reference on this topic.

\section{METHODS}

A prospective and randomized study including 20 patients who underwent abdominoplasty was conducted at the $38^{\text {th }}$ Nursing service of Santa Casa de Misericórdia do Rio de Janeiro between March and May 2010.

The inclusion criteria established for the study were clinical indication for abdominoplasty and female gender. The exclusion criteria were history of bariatric surgery, presence of connective tissue diseases, body mass index (BMI) of $>30$, flap suffering, hematoma requiring drainage, postoperative seroma, hypertrophic scarring, and/or keloids.

The patients were randomly divided into two groups: A and B. In group A, classical abdominoplasty was performed according to the technique described by Professor Ivo Pitanguy $^{3}$. The procedure in group B also included lower flap fixation, as explained below.

Professor Pitanguy's technique began with the patient in a prone position, with the arms positioned at 40 degrees in abduction. After asepsis, the midline was marked by a wire placed at the xiphoid appendix and another placed close to the pubis. The incision started in the midline and advanced parallel to the line of the pubic hair, rose following the inguinal crease, and ended at an imaginary line that passed through the anterior superior iliac spine. The incision was made up to the rectus abdominis muscle aponeurosis, and detachment was continued up to the umbilicus. The flap was then split in the midline. A circumferential incision was made around the umbilicus, leaving its pedicle attached to deep structures. Detachment was carried out in a tunnel, using the costal arch as a lateral limit up to the xiphoid process, and posterior plication of the rectus abdominis muscles was carried out with 2.0 nylon.

The back of the patient was elevated to 15 degrees and the upper flap temporarily sutured to the lower flap in the midline. By employing Professor Pitanguy's marker, flap excess was reassessed and resected, and then a vacuum tube was positioned. The umbilicus position was determined in the upper flap; subsequently, a hole was incised in this position, and the fat inside it was resected. Finally, the umbilical scar was sutured, and surgical wound synthesis was performed in three planes.

In Group B, lower flap fixation was performed by placing seven stitches, the first one in the midline and the others divided bilaterally, every $4 \mathrm{~cm}$. Simple stitches were made using 2.0 nylon to suture the rectus abdominis fascia muscle aponeurosis and Scarpa's fascia in the midline and the external oblique muscle aponeurosis on the sides (Figure 1).

Scar assessment was carried out at both two weeks and six months after operation. On these occasions, three measurements were obtained: distance from the xiphoid process to the scar, distance from the pubis to the scar, and distance from the xiphoid process to the pubis.

The anterior portion of the patients was photographed in supine position, from the chest to the pubis and with the hip leaning against a wall, in order to avoid bias. The heights of the iliac crests were also verified, so that the patient was in
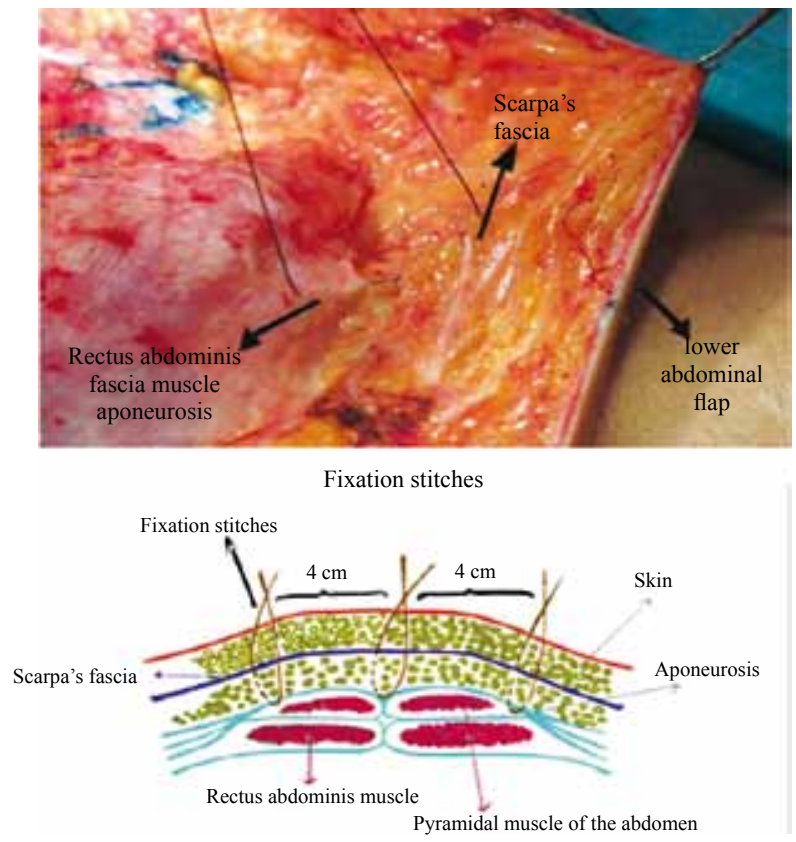

Figure 1 - Fixation stitches of the lower abdominal flap. 
the same position on both visits. Fixed points of reference (xiphoid process and pubis) were marked with a pen on the skin of the patient and verified in the photographs. Markings and scales were required for accurate measurements of vertical distances.

Digital photography software was used to obtain seven vertical measurements. In each photograph, a horizontal line was drawn through the pubis. At every $4 \mathrm{~cm}$ from the midline, the vertical distance from the horizontal line to the scar was measured. Measurements were obtained with two reference scales, one placed beside the patient and another on the digital software (Figure 2).

At each point, vertical migration of the scar was measured by subtracting the vertical distance measured at six months from the vertical distance measured two weeks postoperatively. After measurements were obtained in both groups, the average vertical migration in the control and flap fixation groups was subtracted to obtain the difference in average vertical migration between the groups.

\section{RESULTS}

Four patients were excluded from the study (two patients in each group); three patients were excluded due to seroma and one due to partial necrosis in the flap.

In group A, patient age ranged from 30 to 60 years (average, 45.4 years). The height of these patients ranged from $1.55 \mathrm{~m}$ to $1.70 \mathrm{~m}$ (average, $1.62 \mathrm{~m}$ ). The average weight was $65.7 \mathrm{~kg}$, ranging from $58.4 \mathrm{~kg}$ to $76.9 \mathrm{~kg}$. The average BMI was $25 \mathrm{~kg} / \mathrm{m}^{2}$, with a minimum of $23.3 \mathrm{~kg} / \mathrm{m}^{2}$ and a maximum of $26.6 \mathrm{~kg} / \mathrm{m}^{2}$.

In group $\mathrm{B}$, the average age was 45 years, ranging from 26 to 59 years. The average height was $1.60 \mathrm{~m}$, ranging from $1.54 \mathrm{~m}$ to $1.67 \mathrm{~m}$. The weight ranged from $55 \mathrm{~kg}$ to $75 \mathrm{~kg}$ and was $61.1 \mathrm{~kg}$ on average. The average BMI was $24 \mathrm{~kg} /$ $\mathrm{m}^{2}$, ranging from $21.8 \mathrm{~kg} / \mathrm{m}^{2}$ to $27.2 \mathrm{~kg} / \mathrm{m}^{2}$.

Demographic differences were not statistically significant $(\mathrm{P}<0.05)$.

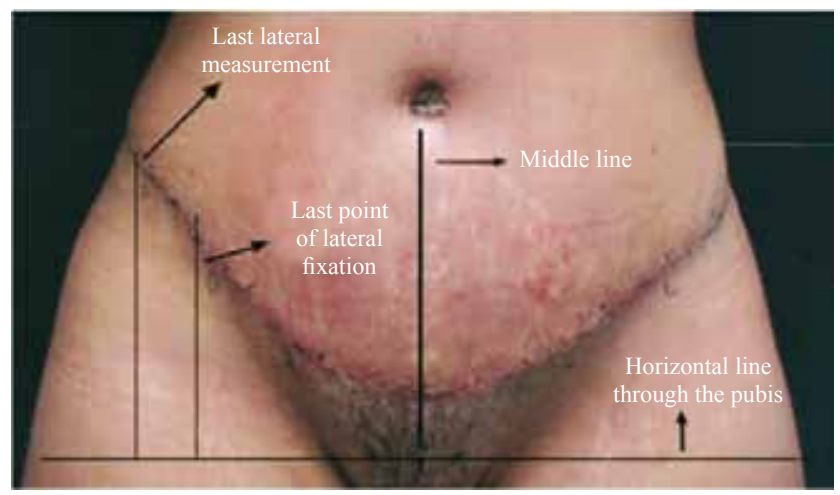

Figure 2-Marks made in the photographs for later measurement.

\section{Assessment of Vertical Scar Migration}

The vertical distances measured two weeks and six months after surgery are included in the tables and figures.

In group $\mathrm{A}$, the average vertical migration in line with the pubis was $0.67 \mathrm{~cm}$, while measurements at $4 \mathrm{~cm}, 8 \mathrm{~cm}$, and 12 $\mathrm{cm}$ to the right and left of the pubis were $0.97 \mathrm{~cm}, 1.10 \mathrm{~cm}$, and $1.14 \mathrm{~cm}$ and $0.9 \mathrm{~cm}, 1.06 \mathrm{~cm}$, and $1.62 \mathrm{~cm}$, respectively. The overall average vertical migration in group A was 1.06 $\pm 0.63 \mathrm{~cm}$ (Figure 3).

In group $\mathrm{B}$, the average vertical migration in line with the pubis was $0.26 \mathrm{~cm}$, and other measurements at the right and left of the pubis were $0.35 \mathrm{~cm}, 0.77 \mathrm{~cm}$, and $0.96 \mathrm{~cm}$ and 0.33 $\mathrm{cm}, 0.86 \mathrm{~cm}$, and $1.26 \mathrm{~cm}$, respectively. The overall average vertical migration in group B was $0.68 \pm 0.47 \mathrm{~cm}$ (Figure 4).

The average difference between the groups in vertical migration was $0.41 \mathrm{~cm}$ in line with the pubis, while differences in the other measurements $(4 \mathrm{~cm}, 8 \mathrm{~cm}$, and $12 \mathrm{~cm})$ to the right and left of the pubis were $0.62 \mathrm{~cm}, 0.33 \mathrm{~cm}$, and $0.18 \mathrm{~cm}$ and $0.57 \mathrm{~cm}, 0.23 \mathrm{~cm}$, and $0.36 \mathrm{~cm}$, respectively. The average difference between the groups in vertical migration throughout the scar was $0.4 \pm 0.38 \mathrm{~cm}$ (Figure 5).

\section{DISCUSSION}

Several variables must be considered in order to obtain a desirable scar. First, the scar location directly depends on the positioning of the incisions. Incision positioning has changed over the years, following cultural changes and women's clothing trends to accommodate the resulting scar and prevent its exposure ${ }^{4-7}$. For instance, in 1995, Professor Pitanguy ${ }^{8}$ changed the lateral incision from a downward to an upward arch.

The second variable to be considered is incision length. The incision is directly related to sagging and skin excess, which will guide the surgeon in determining the optimal incision length.

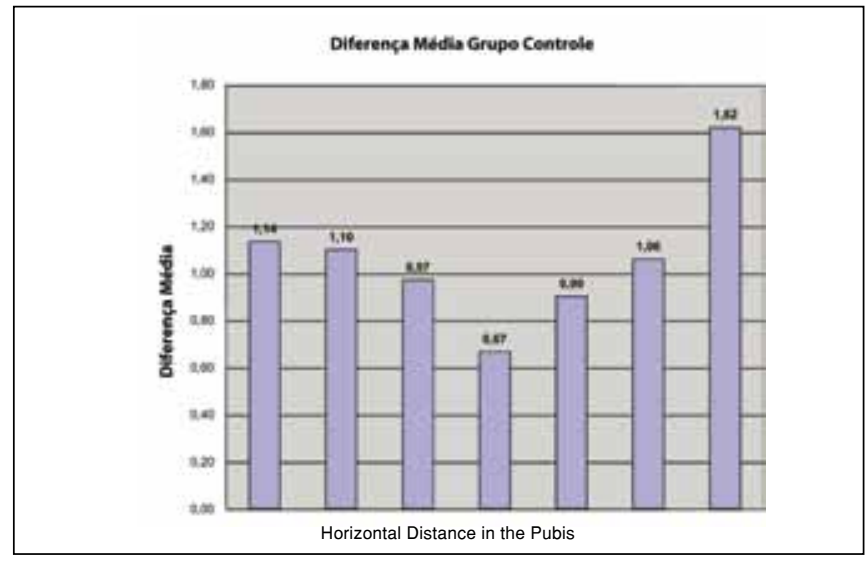

Figure 3 -Average vertical migration in the pubis in group $A$. 


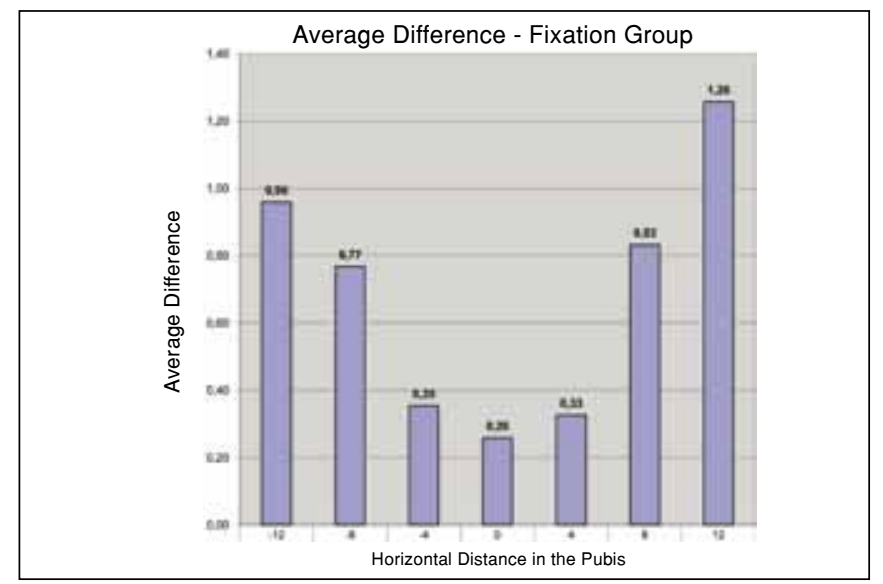

Figure 4-Average vertical migration in the pubis in group $B$.

The third variable relates to the healing process ${ }^{9}$, which includes several aspects, many of which are atavistic and beyond the surgical team's control ${ }^{10}$. However, tension on the sutures plays an essential role and is largely responsible for scar retraction by vertical migration, scar enlargement, and scar shape. Suture tension may change their convexity or even decrease flap nutrition, leading to complications such as necrosis and dehiscence.

The anatomical principles studied by Lockwood ${ }^{11}$ should be valued, in particular the importance of the superficial fascial system in fixing the thigh flap ${ }^{12}$, and subsequently, in 1995, in abdominoplasty itself. Furthermore, anatomical knowledge of the rectus abdominis muscle sheath and fascial composition of the external, internal, and transverse oblique muscles also plays an important role in abdominoplasty ${ }^{11,13,14}$. This knowledge aided the development of a fixation method using firm structures such as the rectus abdominis muscle aponeurosis in the midline and the external oblique muscle on the sides, with sutures involving these tissues and Scarpa's fascia ${ }^{15}$.

Surprisingly, vertical scar migration was greater on the sides in relation to the midline. This result may be due to greater looseness in the lateral tissues, enabling a greater rise with minimal traction.

The difference in average migration between the groups was greater in the midline. The explanation for this result may lie in the fact that the fixation stitches were passed every $4 \mathrm{~cm}$, following the edge of the incision. However, vertical measurements using the photographs were obtained every $4 \mathrm{~cm}$, following a horizontal line through the fixed stitch in the pubis. Therefore, the last measurement point was in a more lateral position than the last fixation stitch. Thus, measurements at $+12 \mathrm{~cm}$ and $-12 \mathrm{~cm}$ were carried out in areas where there was no fixation of the lower flap, and the difference between these measurements was negligible in groups $\mathrm{A}$ and $\mathrm{B}$.

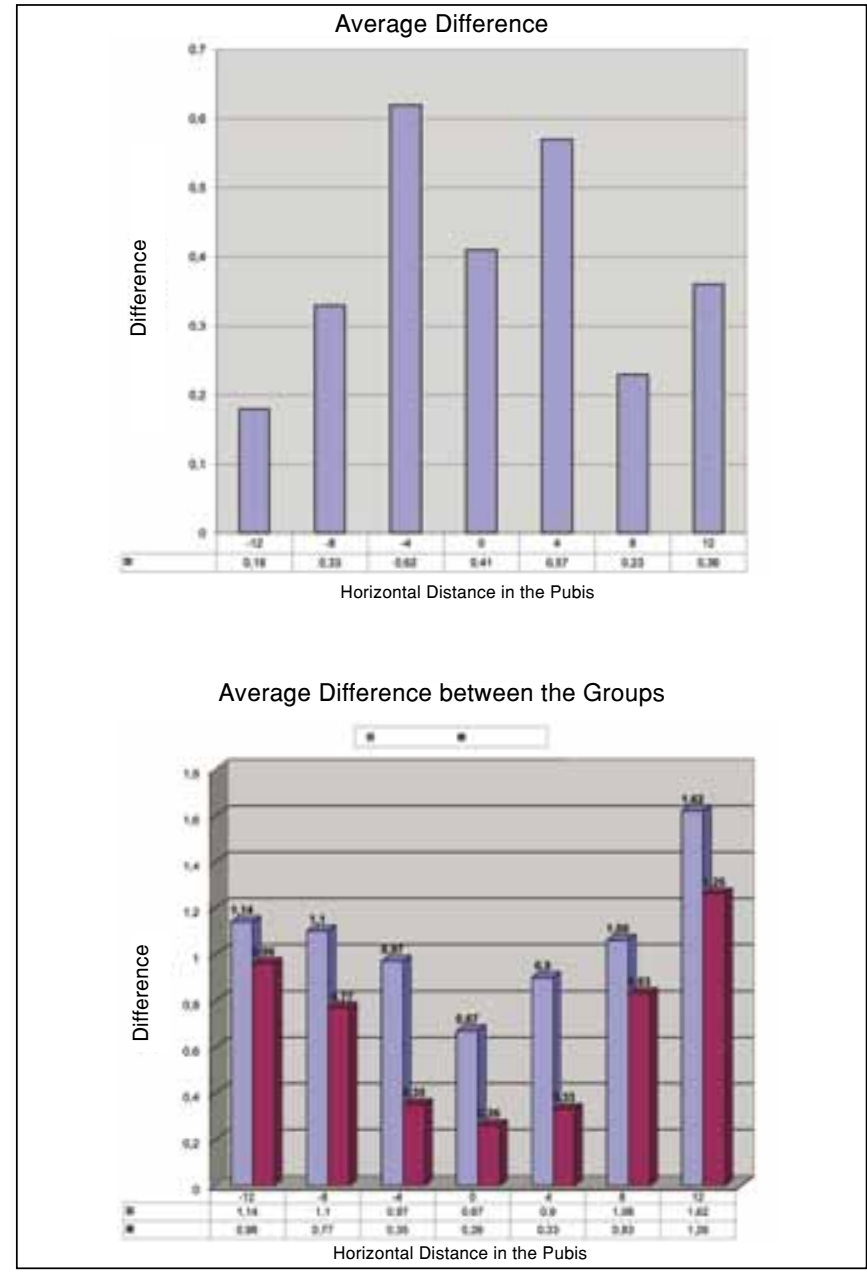

Figure 5 - Differences in average vertical migration.

If the side measurements are not included in the assessment of the average vertical migration difference between the groups, the value obtained is $0.72 \pm 0.3 \mathrm{~cm}$.

The lower flap was chosen to be fixed as it is a structure that does not undergo detachment and indicates the exact position where the surgeon desires the scar to be.

\section{CONCLUSIONS}

Understanding the natural evolution of a scar is of great value in plastic surgery, especially for better preoperative planning of the incision.

This study demonstrated a vertical migration of up to 1.62 $\mathrm{cm}$ laterally and $0.67 \mathrm{~cm}$ medially in group A and vertical migration of up to $1.26 \mathrm{~cm}$ vertically and $0.26 \mathrm{~cm}$ medially in group B with lower flap fixation. In both groups, migration was lower in the midline and greater on the sides.

The difference between the groups in average vertical migration throughout the scar was $0.72 \pm 0.3 \mathrm{~cm}$. 
Given these results, it is possible to recommend fixation of the lower abdominal flap in abdominoplasty, since the variation in scar migration found between the two groups could represent the difference between an unsightly scar and a hidden scar.

\section{REFERENCES}

1. Sinder R. Abdominoplastias. In: Carreirão S, Cardim V, Goldenberg D, eds. Cirurgia Plástica: Sociedade Brasileira de Cirurgia Plástica. São Paulo: Atheneu; 2005. p. 621-46.

2. Friedland JA, Maffi TR. Abdominoplasty. Plast Reconstr Surg. 2008;121(4 Suppl):1-11.

3. Pitanguy I. Abdominal lipectomy: an approach to it through an analysis of 300 consecutive cases. Plast Reconstr Surg. 1967;40(4):384-91.

4. Dini GM. Anew position to hide the abdominoplasty scar. Plast Reconstr Surg. 2007;119(4):1391-2.

5. Marking and operative techniques. Plast Reconstr Surg. 2006;117(1 Suppl):45S-73S.
6. MomeniA,HeierM,BannaschH,Torio-Padron N, Stark GB. The "risingsun-technique" in abdominoplasty. Ann Plast Surg. 2008;60(4):343-8.

7. Potter JA, Griffin PA. Triangulation for abdominoplasty. Plast Reconstr Surg. 2010;125(6):264e-6e.

8. Pitanguy I. Abdominoplastias. O Hospital. 1967;71(6):1541-56.

9. Janis JE, Kwon RK, Lalonde DH. A practical guide to wound healing. Plast Reconstr Surg. 2010;125(6):230e-44e.

10. van der Veer WM, Ferreira JA, de Jong EH, Molema G, Niessen FB. Perioperative conditions affect long-term hypertrophic scar formation. Ann Plast Surg. 2010;65(3):321-5

11. Lockwood T. High-lateral-tension abdominoplasty with superficial fascial system suspension. Plast Reconstr Surg. 1995;96(3):603-15.

12. Lockwood TE. Fascial anchoring technique in medial thigh lifts. Plast Reconstr Surg. 1988;82(2):299-304.

13. Lockwood T. Lower body lift with superficial fascial system suspension. Plast Reconstr Surg. 1993;92(6):1112-22.

14. Lockwood TE. Superficial fascial system (SFS) of the trunk and extremities: a new concept. Plast Reconstr Surg. 1991;87(6):1009-18.

15. April EW. NMS clinical anatomy. $3^{\text {rd }}$ ed. Philadelphia: Williams \& Wilkins; 1997.

\section{Correspondence to:}

Vinícius Volpe D'Angieri Basile

Av. General San Martin, 856 - ap. 302 - Rio de Janeiro, RJ, Brazil - CEP 22441-014

E-mail: vimedbasile@hotmail.com 